\title{
Coeliac disease with mild mucosal abnormalities: a report of four patients
}

\author{
BRIAN B. SCOTT \\ M.D., M.R.C.P.
}

\author{
M. S. LosowsKY \\ M.D., F.R.C.P.
}

\author{
University Department of Medicine, St James's Hospital, Leeds LS9 7TF
}

\begin{abstract}
Summary
In a routine adult gastroenterological practice, seventeen $(15 \%)$ of 123 patients had small-intestinal biopsies which were neither normal nor were completely flat as found in classical coeliac disease. Some of these had a possible cause for the mild mucosal abnormality, but in six there was no other apparent cause and all four of these who were treated with a gluten-free diet responded morphologically and symptomatically. It is concluded that at least these four patients have coeliac disease in a mild form and that the classical flat biopsy is not a prerequisite for the diagnosis of coeliac disease.
\end{abstract}

\section{Introduction}

Probably few would disagree that coeliac disease is that condition in which there is an abnormality of the small-intestinal mucosa caused by dietary gluten. However, the criteria for diagnosis vary greatly. Some demand no less than a flat mucosa with malabsorption (Weinstein et al., 1970), some require only a flat mucosa (Cooke and Asquith, 1974), and some do not specify the degree of mucosal abnormality (Booth, 1970; Stewart, 1974). A morphological response to gluten withdrawal, either with (Booth, 1974) or without (Weinstein et al., 1970; Booth, 1970) subsequent deterioration following gluten re-introduction, has been required to demonstrate gluten sensitivity. However, what constitutes a response has not been defined and usually the effect of patchiness of mucosal abnormality (Scott and Losowsky, 1975) has not been taken into account. Patients with probable coeliac disease and a mild mucosal lesion have been described (Girdwood et al., 1966; Challacombe et al., 1975; McConnell and Whitwell, 1975; Dellipiani, 1975; Robinson et al., 1971; Fry et al., 1974). However, except in association with dermatitis herpetiformis, there is a reluctance to accept such lesser abnormalities as indicative of coeliac disease (McConnell and Whitwell, 1975) and indeed some of the above definitions would deny this possibility.

This study was designed to assess the frequency of milder mucosal abnormalities in routine adult gastroenterological practice and to document, with the aid of multiple biopsies, that at least some of these respond morphologically to a gluten-free diet. and should be classified as coeliac disease. As far as $\overrightarrow{\vec{\omega}}$ the authors are aware, the response to a gluten-free $\omega$ diet has not previously been documented in such? patients using multiple biopsies to overcome the 3 . problem of sampling error, except in dermatitise herpetiformis (Brow et al., 1971).

\section{Methods}

Small-intestinal biopsies from 123 consecutive $\stackrel{\omega}{\oplus}$ patients with suspected malabsorption being biopsied 음 for the first time were studied. Ages ranged from 14to 80 years (mean 40 years), All biopsies were taken 3 in the department of gastroenterology using the $\frac{0}{\widehat{O}}$ hydraulic multiple biopsy tube (Quinton Instru- ments, Seattle) this being the instrument routineßy $\overrightarrow{0}$ used in this department. Three or four biopsies wee. taken from the jejunum just past the duodenầi junction. Biopsies were immediately graded 厚京 stereomicroscopy as villous (leaf or finger shaped), ridged, convoluted or flat (Barry et al., 1971), the villous appearance being considered as normal. $\frac{\AA}{\circ}$ Later they were randomized and graded by blind $\stackrel{2}{\vec{A}}$ subjective histological assessment (Rubin et al., 1960) as follows: grade 1 (normal: no shortening of villi or lengthening of crypts); grade 2 (slight partial villous atrophy, slight shortening of villi and lengthening of crypts); grade 3 (marked partial $\frac{5}{3}$ villous atrophy, marked shortening of villi and lengthening of crypts); grade 4 (subtotal villous atrophy, no definite villous structure). Sections which were incorrectly oriented were discarded to avoid the tangential artefact (Rubin et al., 1960).

\section{Results}

The grading of the biopsies by both stereomicroscopy and histology is shown in Table 1. De- $\odot$ tails of the patients with ridged and convoluted N mucosae are presented individually. In two of the స్త patients the histological sections were incorrectly $\sigma$ oriented and it was not possible accurately to grade

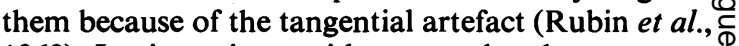
1960). In six patients with a convoluted mucosa no other cause could be found. One of these had con- 0 volutions in only one of seven biopsies (the others ${ }^{-}$

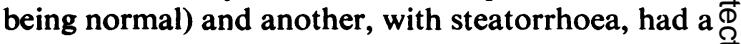


TABLE 1. The grading of biopsies from 123 consecutive patients

\begin{tabular}{|c|c|c|c|}
\hline Stereomicroscopy & Number & $\begin{array}{c}\text { Histology } \\
\text { grade } †\end{array}$ & Diagnosis \\
\hline Villous & 95 & 1 & Various \\
\hline Ridged & 6 & $\begin{array}{l}1 \\
? \\
? \\
1-2 \\
1-3^{*} \\
2\end{array}$ & $\begin{array}{l}\text { Chronic active hepatitis } \\
\text { Crohn's disease } \\
\text { Cystic fibrosis } \\
\text { Iron and folate deficiency, hepatomegaly } \\
\text { Dermatitis herpetiformis } \\
\text { Weight loss? cause }\end{array}$ \\
\hline Convoluted & 11 & $\begin{array}{l}2-3 \\
2 \\
2 \\
1-2^{*} \\
2-3^{*} \\
1-2 \\
1 \\
2-3^{*} \\
2-3^{*} \\
2-4^{*} \\
2-4^{*}\end{array}$ & $\begin{array}{l}\text { Tropical sprue } \\
\text { Pancreatitis } \\
\text { Severe ichthyosis } \\
\text { Dermatitis herpetiformis } \\
\text { Dermatitis herpetiformis } \\
\text { No other cause found }\end{array}$ \\
\hline Flat & $11^{*}$ & 4 & Coeliac disease \\
\hline
\end{tabular}

* Subsequently treated with a gluten-free diet.

+ See text.

TABLe 2. Results of tests for malabsorption

\begin{tabular}{|c|c|c|c|c|c|}
\hline \multirow[b]{2}{*}{ Test } & \multicolumn{4}{|c|}{ Patient } & \multirow{2}{*}{$\begin{array}{l}\text { Normal } \\
\text { values }\end{array}$} \\
\hline & 1 & 2 & 3 & 4 & \\
\hline $\begin{array}{l}\text { Haemoglobin }(g / d l) \\
\text { Blood film* }\end{array}$ & $\begin{array}{c}7 \cdot 9 \\
\text { MIC } \\
\text { HYP }\end{array}$ & $\begin{array}{l}13 \cdot 6 \\
\mathrm{~N}\end{array}$ & $\begin{array}{l}11 \cdot 3 \\
\text { MIC } \\
\text { HYP } \\
\text { TAR }\end{array}$ & $\begin{array}{l}12 \cdot 2 \\
\text { MAC } \\
\text { TAR }\end{array}$ & \\
\hline Serum iron $(\mu \mathrm{mol} / 1)$ & $4 \cdot 1$ & $17 \cdot 0$ & $4 \cdot 5$ & $32 \cdot 2$ & $>10.7$ \\
\hline Serum folate $(\mu \mathrm{g} / 1)$ & $5 \cdot 7$ & $3 \cdot 2$ & $12 \cdot 8$ & $3 \cdot \overline{3}$ & $>3.0$ \\
\hline Serum $B_{12}(\mathrm{ng} / \mathrm{l})$ & 90 & $\dagger$ & 205 & 95 & $>110$ \\
\hline Serum albumin $(g / 1)$ & 29 & 40 & 44 & 50 & $>37$ \\
\hline Serum calcium (mmol/l) & $2 \cdot 0$ & $2 \cdot 3$ & $2 \cdot 4$ & $2 \cdot 4$ & $>2 \cdot 25$ \\
\hline Serum alkaline phosphatase (KA units) & 19 & 8 & 6 & 5 & $<13$ \\
\hline Serum carotene $(\mu \mathrm{mol} / \mathrm{l})$ & 0.58 & $1 \cdot 24$ & - & 0.69 & $>0.74$ \\
\hline Serum vitamin $A(\mu \mathrm{mol} / 1)$ & $1 \cdot 27$ & $1 \cdot 22$ & - & $1 \cdot 57$ & $>1.05$ \\
\hline Serum vitamin E $(\mu \mathrm{mol} / 1)$ & $19 \cdot 3$ & $12 \cdot 4$ & - & $12 \cdot 0$ & $>12 \cdot 2$ \\
\hline Leucocyte vitamin C (fmol/WBC) & 0.85 & $6 \cdot 82$ & - & $4 \cdot 7$ & $>0.83$ \\
\hline Prothrombin time (sec) & 14 & 12 & 12 & 13 & $<14$ \\
\hline Xylose test & $6 \%$ & $22 \%$ & $34 \%$ & $28 \%$ & $>22 \%$ \\
\hline Faecal fat $(\mathrm{mmol} / 24 \mathrm{hr})$ & 11 & 49 & 14 & 17 & $<18$ \\
\hline Urinary indican $(\mathrm{mmol} / 24 \mathrm{hr})$ & $0 \cdot 19$ & - & 0.07 & 0.37 & $<0.47$ \\
\hline
\end{tabular}

* MIC, microcytic; MAC, macrocytic; HYP, hypochromic: TAR, target cells.

$\dagger$ Receiving intramuscular $\mathbf{B}_{12}$.

$\ddagger$ Percentage of $5 \mathrm{~g}$ oral xylose excreted in urine in next $5 \mathrm{hr}$.

mixture of both villi and convolutions in most biopsies. Neither was treated with a gluten-free diet. The remaining four were all treated with a glutenfree diet and are described in more detail.

\section{Case reports}

The results of tests of absorption are shown in
Table 2. The results of jejunal biopsy before and after a gluten-free diet are shown in Table 3. A biopsy showing convoluted folds representative of the appearance seen in all four patients on stereomicroscopy is shown in Fig. 1. A biopsy taken from patient 4 showing typical slight partial villous atrophy (grade 2) is shown in Fig. 2. 


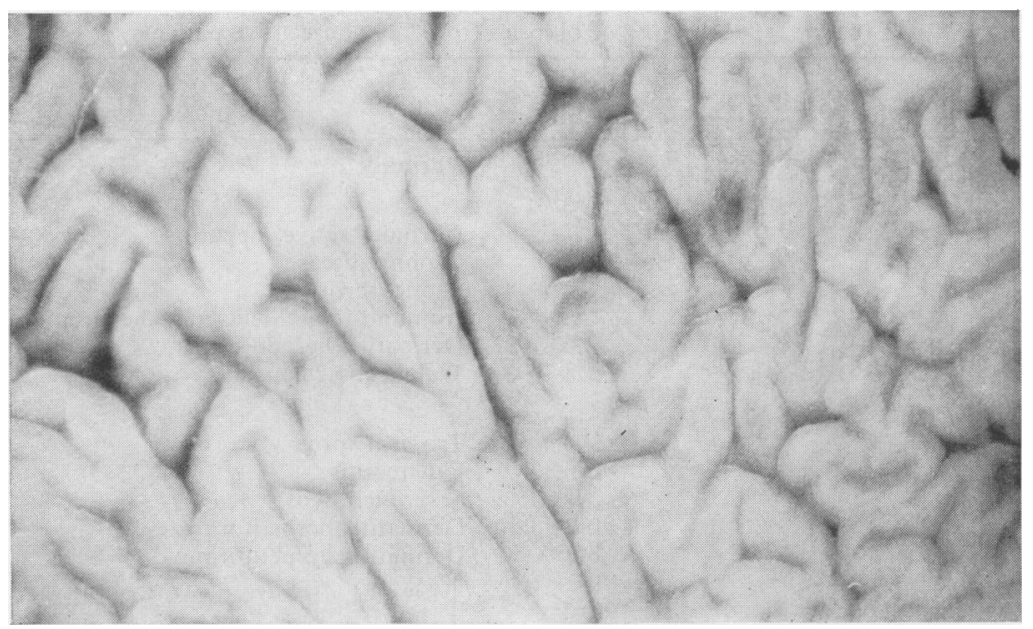

FIG. 1. A biopsy showing convoluted folds representative of the appearance seen on stereomicroscopy in all four patients.

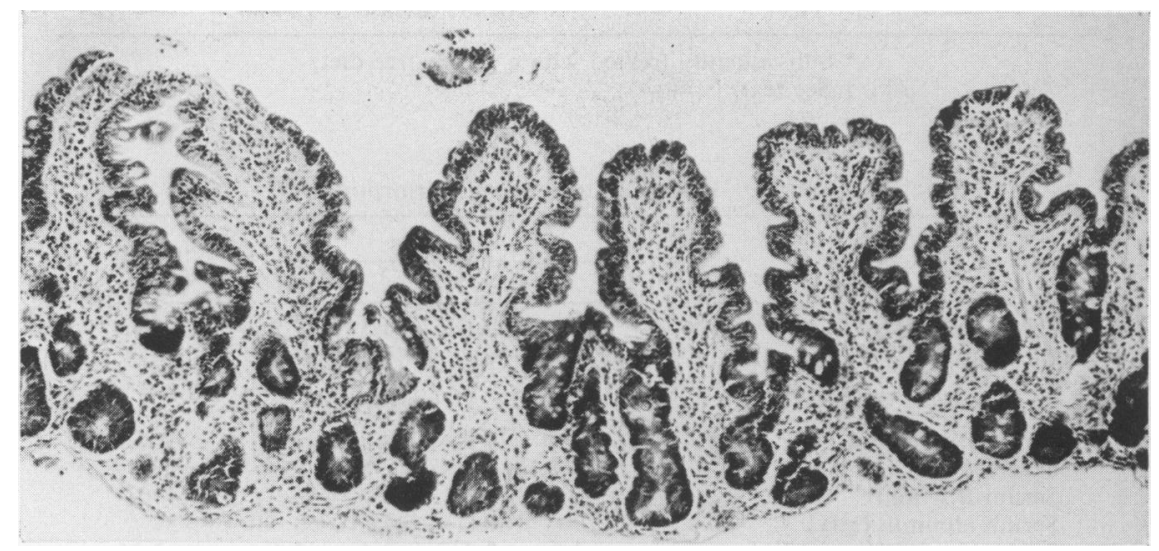

FIG. 2. A biopsy taken from patient 4 before treatment showing typical slight partial villous atrophy (grade 2).

TABLE 3. Details of jejunal biopsies taken from the four patients described

\begin{tabular}{llllll}
\hline Patient & $\begin{array}{c}\text { Gluten-free } \\
\text { diet }\end{array}$ & \multicolumn{4}{c}{ Grading of multiple biopsies* } \\
\hline 1 & Before & C 4 & C 2 & C 3 & \\
& After 2 years & V 1 & V 1 & V 1 & V 2 \\
2 & Before & C 2 & C 3 & C 3 & V 2 \\
& After 0.8 years & V 1 & V 1 & V 1 & \\
3 & Before & C 3 & C 2 & C/F 4 & V \\
4 & After 1.6 years & V 2 & V 2 & V 2 & \\
4 & Before & C 3 & R/C 2 & R 3 & C 3 \\
& After 0.9 years & V/C 2 & V 2 & V 2 & \\
\hline
\end{tabular}

* Stereomicroscopic and histological grade are given for each biopsy, V, villous; $R$, ridged; $C$, convoluted; $F$, flat. In some biopsies, different parts of the same biopsy had different stereomicroscopic appearances.
Patient 1

A 19-year-old girl, referred for investigation of small stature, mental backwardness and failure of 을 sexual development. She appeared well nourished $\supset$ and had no diarrhoea. Examination showed the build and mentality of a 10-year-old and there were $\bar{N}$ no signs of secondary sexual development. On investigation there were various nutritional de- $N$ ficiencies but no steatorrhoea. She was histocom- N patibility type HL-A8 positive, serum reticulin antibodies were not tested for. Radiology showedo

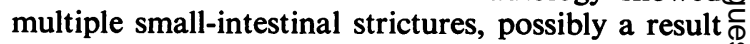
of previous ulceration, a recognized complication of $\stackrel{\oplus}{+}$ coeliac disease (Bayless et al., 1967) although it has 0 not previously been reported in one so young. $\frac{\vec{P}}{\mathrm{D}}$

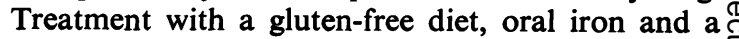


single injection of vitamin $B_{12}$ produced a dramatic improvement. There having been no change of height or weight in the previous 9 years, she gained $9.9 \mathrm{~kg}$ in weight and $5 \mathrm{~cm}$ in height over the next 12 months and all tests of nutrition became normal. After a further 6 months pubic hair had appeared, breast development had occurred and menstruation commenced.

\section{Patient 2}

A 39-year-old man, referred for investigation of epigastric pain for 16 years. Three laparotomies had been carried out and no abnormality found. On the last occasion, 4 years before referral, a pyloroplasty was performed with no improvement. He was later found to be anaemic and was treated with iron, folic acid and vitamin $\mathbf{B}_{12}$. He had no diarrhoea. Radiology showed no significant abnormality of the small intestine. He was HL-A8 positive and serum reticulin antibodies were detected. Within a few days of starting a gluten-free diet he became free of abdominal pain for the first time in 16 years.

\section{Patient 3}

A 40-year-old woman, referred for investigation of iron deficiency anaemia. She had been found to be anaemic 7 years previously when offering to be a blood donor. She had no gastrointestinal symptoms. Her daughter had coeliac disease. She was HL-A8 negative. Serum reticulin antibodies were detected. Small-intestinal radiology was normal. Four months after treatment with a gluten-free diet only, she volunteered that she had much more energy than previously, and without iron therapy her serum iron rose to normal and her blood film became normochromic.

\section{Patient 4}

A 35-year-old woman, referred by a rheumatologist (whom she had attended for 2 years with multiple aches and pains) because of a macrocytic blood film. She had suffered lower abdominal pain $30 \mathrm{~min}$ after meals, relieved by vomiting, for more than a year. She had no diarrhoea. She tired easily. Past thyrotoxicosis had been successfully treated by thyroidectomy. She was clinically euthyroid and this was confirmed by tests of thyroid function. Barium examination of the small intestine showed dilatation, reduced transit time and flocculation. A Schilling test confirmed malabsorption of vitamin $B_{12}$. She was HL-A8 positive and reticulin antibodies were detected. Following treatment with a gluten-free diet she felt generally much better and in particular the abdominal pain and vomiting improved. The blood film became normal without supplements of haematinics.
TABLE 4. Conditions associated with small-intestinal villous atrophy in adults

\begin{tabular}{ll}
\hline $\begin{array}{l}\text { Tropical sprue } \\
\text { Hypogammaglobulinaemia } \\
\text { and giardiasis }\end{array}$ & $\begin{array}{l}\text { Ischaemia } \\
\text { Radiation }\end{array}$ \\
$\begin{array}{l}\text { Other parasitic infection } \\
\text { Tuberculosis }\end{array}$ & $\begin{array}{l}\text { Small-intestinal lymphoma } \\
\text { Malignancy in other sites }\end{array}$ \\
Dermatitis herpetiformis & B $_{12}$ and folate deficiency \\
Other dermatoses & Hepatitis \\
Crohn's disease & Drugs \\
Ulcerative colitis & Eosinophilic gastroenteritis \\
Cystic fibrosis & Soy protein sensitivity \\
Whipple's disease & Macroamylasaemia \\
Zollinger-Ellison syndrome & Hypothyroidism \\
Stasis & \\
\hline
\end{tabular}

\section{Discussion}

In a routine adult gastroenterological practice, $15 \%$ of these patients being biopsied for the first time had small-intestinal mucosa which was neither completely normal nor had the severe abnormality found in classical coeliac disease. In some of these patients with intermediate abnormalities (particularly those with ridges) some other diagnosis was made which could possibly explain the mucosal lesion, although without a trial of a gluten-free diet coeliac disease could not be excluded with certainty. However, in six patients no other cause could be found and all four of these who were treated with a gluten-free diet responded morphologically and symptomatically. The authors feel confident, therefore, that at least these four patients have coeliac disease, albeit in a milder form than classically described. To their knowledge this is the first time patients with mild abnormalities (except those with dermatitis herpetiformis) have been shown to respond unequivocally to gluten withdrawal using multiple biopsies to overcome sampling error.

Although serum folate levels were at the lower end of the normal range in two patients, in none was the level subnormal. This is an unusual finding in untreated coeliac disease and may reflect the mild mucosal abnormality. Patient 1 was given oral iron and intramuscular vitamin $\mathbf{B}_{12}$ simultaneously with the gluten-free diet and the possibility must be considered that the response may have been due to these haematinics rather than to the gluten-free diet. $\mathbf{B}_{12}$ deficiency has been shown to cause abnormalities of the small-intestinal epithelial cells but probably without significant impairment of intestinal function (Foroozan and Trier, 1967). Iron deficiency anaemia has been shown to cause villous atrophy in children (Guha et al., 1968) but studies in adults have shown normal villi (Rawson and Rosenthal, 1960). Moreover, patient 1 remains extremely well 4 years after treatment with a gluten-free diet although oral iron was stopped after 1 year.

It is concluded that mild mucosal abnormalities occur in untreated coeliac disease and this disease 
should be considered if an otherwise unexplained mucosal abnormality is found, whatever the severity. In dermatitis herpetiformis an increase of interepithelial lymphocytes alone is suggested as an abnormality indicating possible coeliac disease (Fry et al., 1974) and it seems likely that the same may be true of coeliac disease unaccompanied by dermatitis herpetiformis. Indeed in time it may be revealed that there are even more sensitive techniques for recognizing a mucosal abnormality in coeliac disease, e.g. electron microscopy or enzyme studies (McNicholl, Egan-Mitchell and Fottrell, 1974).

The diagnosis of mild coeliac disease will not always be straightforward. Some patients with other small-intestinal disease (tropical sprue and Crohn's disease) may show some evidence of sensitivity to gluten (Bayless and Swanson, 1964; Rudman et al., 1971), presumably secondary to prior mucosal damage. Mild mucosal abnormalities are less specific for coeliac disease than is a flat mucosa and should evoke a greater diagnostic effort in view of the many other possible causes, some of which are listed in Table 4.

Because of patchiness of mucosal abnormality, it is more likely that the more specific flat mucosa will be detected by taking multiple biopsies, and multiple biopsies are essential in assessing response to therapy. It is suggested that the criterion for diagnosis of coeliac disease should be the demonstration of an unequivocal improvement of any mucosal abnormality in response to a gluten-free diet, or deterioration in response to gluten.

\section{References}

Barry, R.E., Salmon, P.R., Read, A.E. \& Warin, R.P. (1971) Mucosal architecture of the small bowel in cases of psoriasis. Gut, 12, 873.

Bayless, T.M., Kapelowitz, R.F., Shelley, W.M., BalLINGER, W.F. \& HENDRIX, T.R. (1967) Intestinal ulceration-a complication of celiac disease. New England Journal of Medicine, 276, 996.

Bayless, T.M. \& Swanson, V.L. (1964) Comparison of tropical sprue and adult celiac disease. Gastroenterology, 46, 731.

BooTH, C.C. (1970) Enterocyte in coeliac disease. British Medical Journal, 3, 725.

Bоoтн, C.C. (1974) Definition of adult coeliac disease. In: Coeliac Disease (Ed. by W. Th. J. M. Hekkens and A. S. Pena), p. 17. Stenfert Kroese, Leiden.
Brow, J.R., Parker, F., Weinstein, W.M. \& Rubin, C.E (1971) The small intestinal mucosa in dermatitis herpeti formis. Gastroenterology, 60, 355.

Challacombe, D.N., Dawkins, P.D., Baylis, J.M. \& ROBERTSON, K. (1975) Small-intestinal histology in coelia disease. Lancet, i, 1345.

COOKE, W.T. \& AsQUith, P. (1974) Introduction and deO finition. In: Clinics in Gastroenterology-Coeliac Diseas $\varepsilon_{\sigma}$ (Ed. by W. T. Cooke and P. Asquith), p. 3. Saunders London.

Dellipiani, A.W. (1975) Small-intestinal histology in coeliac disease. Lancet, ii, 550.

Foroozan, P. \& TRIER, J.S. (1967) Mucosa of the smalp intestine in pernicious anemia. New England Journal of Medicine, 227, 553.

Fry, L., Seah, P.P., Harper, P.G., Hoffbrand, A.V. \& McMinN, R.M.H. (1974) The small intestine in dermatitis herpetiformis. Journal of Clinical Pathology, 27, 817.

Girdwood, R.H., Williams, A.W., McManus, J.P.A. Dellipiani, A.W., Delamore, I.W. \& Kershaw, P.W (1966) Jejunal biopsy in patients with malabsorptive disease Scottish Medical Journal, 11, 343.

Guha, D.K., Walia, B.N.S., Tandon, B.N., Deo, M.G. \& GHAI, O.P. (1968) Small bowel changes in iron-deficiency anaemia of childhood. Archives of Disease in Childhood, $43 \vec{\omega}$

McConnell, R.B. \& Whitwell, F. (1975) Small-intestinaf histology in coeliac disease. Lancet, ii, 418.

McNicholl, B., Egan-Mitchell, B. \& Fottrell, P.F (1974) Varying gluten susceptibility in coeliac disease. In Coeliac Disease (Ed. by W. Th. J. M. Hekkens and A. S $\bar{\Omega}$ Pena), p. 413. Stenfert Kroese, Leiden.

Rawson, A. \& Rosenthal, F.D. (1960) The mucosa of ghe stomach and small intestine in iron deficiency. Lanceto $i, y$ 730.

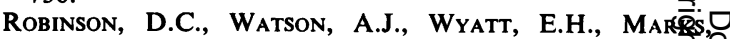
J.M. \& ROBERTS, D.F. (1971) Incidence of small-intestima mucosal abnormalities and of clinical coeliac disease in? the relatives of children with coeliac disease. Gut, 12 금 789.

Rubin, C.E., Brandborg, L.L., Phelps, P.C. \& TAylor H.C. (1960) Studies of celiac disease. Gastroenterology 38, 28.

Rudman, D., Galambos, J.T., Wenger, J. \& AChord, J.L. (1971) Adverse effects of dietary gluten in four? patients with regional enteritis. American Journal of Clinical Nutrition, 24, 1068.

SvotT, B.B. \& LosowSKY, M.S. (1975) Patchiness of the mucosal abnormality in coeliac disease and dermatitis herpetiformis. Gut, 16, 393.

STEWART, J.S. (1974) Clinical and morphologic response to gluten withdrawal. In: Clinics in Gastroenterology- $\delta$ Coeliac Disease (Ed. by W. T. Cooke and P. Asquith), p.3 109. Saunders, London.

Weinstein, W.M., Shimoda, S.S., Brow, J.R. \& Rubin, C.E을 (1970) What is coeliac sprue? In: Coeliac Disease (Ed. by C. C. Booth and R. H. Dowling), p. 232. Churchill Living stone, Edinburgh and London. 